\title{
A new species of Pseudatrichia Osten Sacken (Diptera: Scenopinidae) from North America
}

\section{SHAUN L. WINTERTON}

Entomology, Queensland Department of Primary Industries \& Fisheries, 80 Meiers Road, Indooroopilly, Queensland, Australia and School of Biological Sciences, University of Queensland, St. Lucia, Queensland, Australia. E-mail: wintertonshaun@gmail.com urn:lsid:zoobank.org:author:37F5AC48-EC3A-47ED-902B-2BD1467CCA72

\begin{abstract}
A new species of the North American genus Pseudatrichia Osten Sacken is described. Pseudatrichia bezarki sp. nov. is described based on a male and female reared from wood-boring beetle galleries in Pinus sp. from Arizona (United States).
\end{abstract}

Key words: Pseudatrichia, Asiloidea, Therevoid clade, Scenopinidae

\section{Introduction}

Window flies (Diptera: Scenopinidae) are a small family ( $c a .420$ species) of cosmopolitan asiloid flies with an adult body size rarely greater than $5.0 \mathrm{~mm}$. Scenopinids are distributed throughout all major biogeographical regions, but with significant continental endemism at the genus level with very few genera found in more than one biogeographical region (Kelsey 1973).

Pseudatrichia contains 39 species endemic to the New World although the greatest number of species are found in North America where it appears restricted to west of the Rocky Mountain Range (Kelsey 1969, 1973, 1974). The genus is characterised by a head longer than high, wing cell $R_{5}$ closed and elongate glossy body. Pseudatrichia is closely related to Neopseudatrichia Kelsey (Australia), Prepseudatrichia Kelsey (Afrotropical, Oriental) and Belosta Hardy (Nearctic), although it appears mostly closely related to the latter based on the shared presence of a pair of large setal brushes on the venter of the male genitalia. As larvae, scenopinids are fossorial predators in friable soils, but larvae of these four genera live as predators in the feeding galleries of larvae of wood boring beetles. The greatly elongate, shiny bodies largely lacking setae are presumed to aid adults in exiting these galleries. Species of Pseudatrichia have also been reared from the nests of birds and of communal burrows of wood rats (Muridae: Neotoma spp.) (Kelsey 1969).

A new species of Pseudatrichia, P. bezarki sp. nov., is described herein from a male and female collected in northern Arizona, bringing the total number of species to 40. Previous keys to species of Pseudatrichia have been published by Kelsey (1969) with supplements by Kelsey (1971, 1974). Pseudatrichia bezarki sp. nov. is diagnosed and a key supplement provided.

\section{Materials and methods}

Genitalia were macerated in $10 \% \mathrm{KOH}$ at room temperature for one day to remove soft tissue, then rinsed in distilled water and dilute acetic acid, and dissected in $80 \%$ ethanol. Preparations were then placed into 
glycerine, with images made with the aid of a digital camera mounted on a stereomicroscope. Genitalia preparations were placed in glycerine in a genitalia vial mounted on the pin beneath the specimen. Types are deposited in the California Academy of Sciences Collection (CASC) San Francisco, USA.

\section{Taxonomy}

Pseudatrichia bezarki sp. nov.

urn:Isid:zoobank.org:act:1C82C4FB-C439-4423-BBB0-75FAEA157AC2

(Figures 1-4)

Type Material. Holotype male, UNITED STATES: Arizona: Coconino County: Oak Creek Canyon, [14.5 km] S Flagstaff, on highway, [2010m], L. Bezark, J. Cope, C. Kitayama \& R. Morrison, [35.067 $\left.{ }^{\circ},-111.684^{\circ}\right]$; emerged March 1975; reared from Pinus sp. (CASC). Paratype: female, same data as holotype (CASC).

Diagnosis. Wing hyaline in both sexes; haltere stem dark, knob white except for brown base; distiphallus apically broad and spatulate with posteroventral lobes; gonostylar setal brushes not extending beyond posterior margin of gonocoxites; female sternite 8 medially emarginate posteriorly.

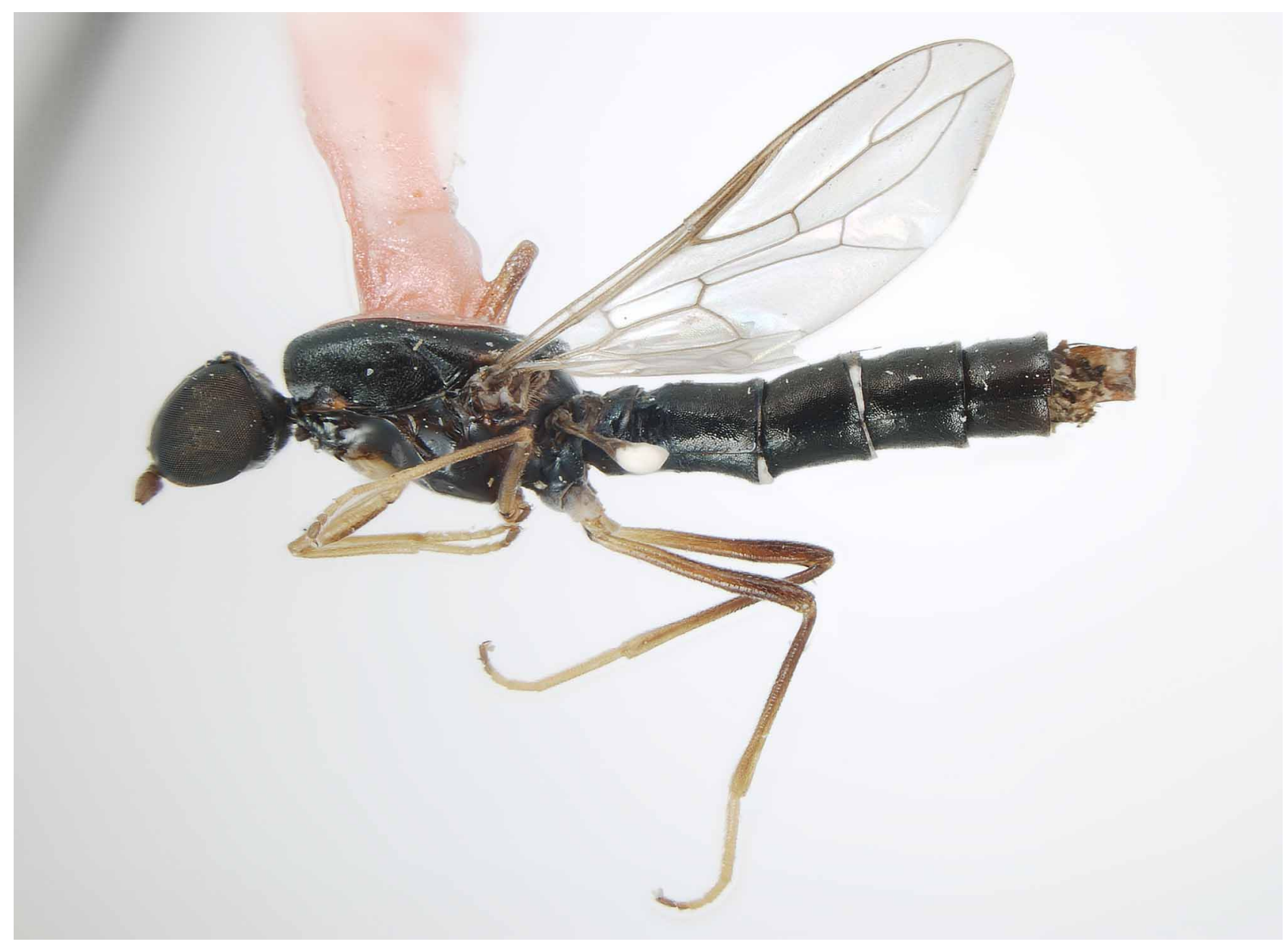

FIGURE 1. Pseudatrichia bezarki sp. nov.: Holotype male, lateral. Body length= $4.8 \mathrm{~mm}$.

Description. Body length, male: $4.8 \mathrm{~mm}$; female $4.4 \mathrm{~mm}$. Head. Glossy black (Figures 1-3); frons profile not protruding anteriorly beyond eye, males with eyes almost contiguous at narrowest point, frons much wider in female; face black, parafacia narrow, glabrous; mouthparts relatively small, but apparently functional, brown; antenna tan-brown, overlain with silvery pubescence, admixed with short dark setae on scape and pedicel; ocellar tubercle flat, overlain with silvery pubescence; postocular ridge very narrow, with minute 
setae laterally but lacking macrosetae; occiput relatively flat to concave dorso-medially, slightly verrucous; gena sparsely covered with fine brown setae. Thorax. Glossy black, scutum finely verrucous, sparsely overlain with short pale setae; postpronotal and pteropleural ridges with small pale tan areas; pleuron smooth and glabrous, except for a few sparse fine setae; coxae and legs pale yellow except for dark brown apical $1 / 4$ of hind femur and base of hind tibia; coxae overlain with silver-white pubescence; pale setae on legs; haltere stem and base of knob dark brown, rest of knob bright white; wing hyaline, venation dark yellow. Abdomen. Glossy black, cylindrical; pitted verrucous over entire surface, overlain with sparsely distributed short pale setae; intersegmental membranes of segments 2-3 white with matt black region medially. Male genitalia (Figure 4A-B). Epandrium shape 'tulip'-like in dorsal view, with posterior margins flared laterally, halves not completely enclosing gonocoxites; cerci narrow and apicies bent medially; gonocoxite with triangular processes along dorsal surface; gonocoxal apodeme relatively broad; hypandrium apparently fused to gonocoxites posteriorly; gonostyli as rounded sclerites covered with densely arranged posteroventrally directed brushes of large setae; distiphallus spatulate apically with medial recurved processes and lateral lobes, posterior surface of distiphallus covered with minute spines; ventral apodeme forked, arms rounded; ejaculatory apodeme small, narrow. Female genitalia (Figure 4C). Sternite 8 red brown, posterior margin hemispherically emarginate, acutely rounded medial process within this margination; cercus directed medially towards apex, sheathed basally.

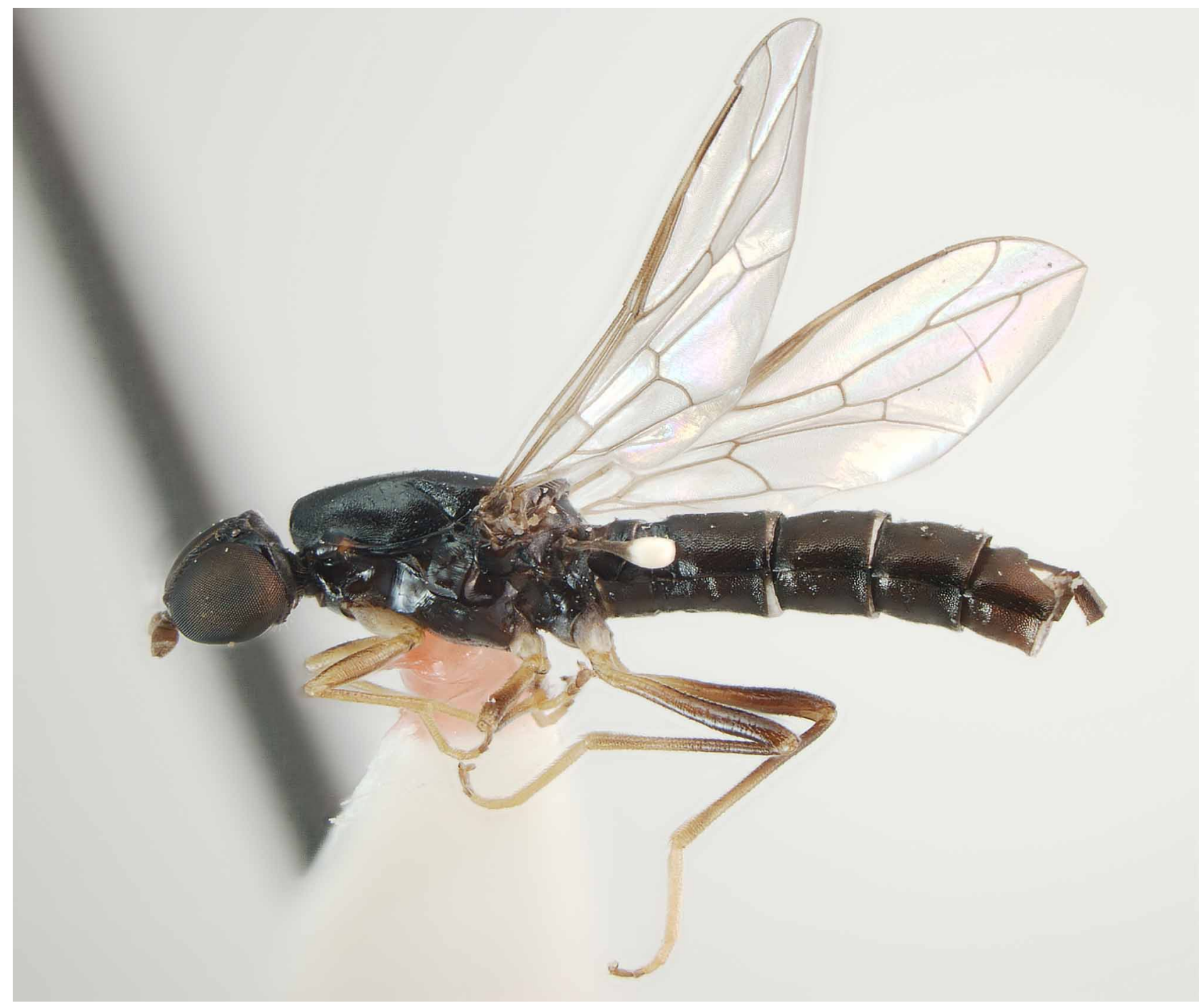

FIGURE 2. Pseudatrichia bezarki sp. nov.: Paratype female, lateral. Body length= $4.4 \mathrm{~mm}$. 


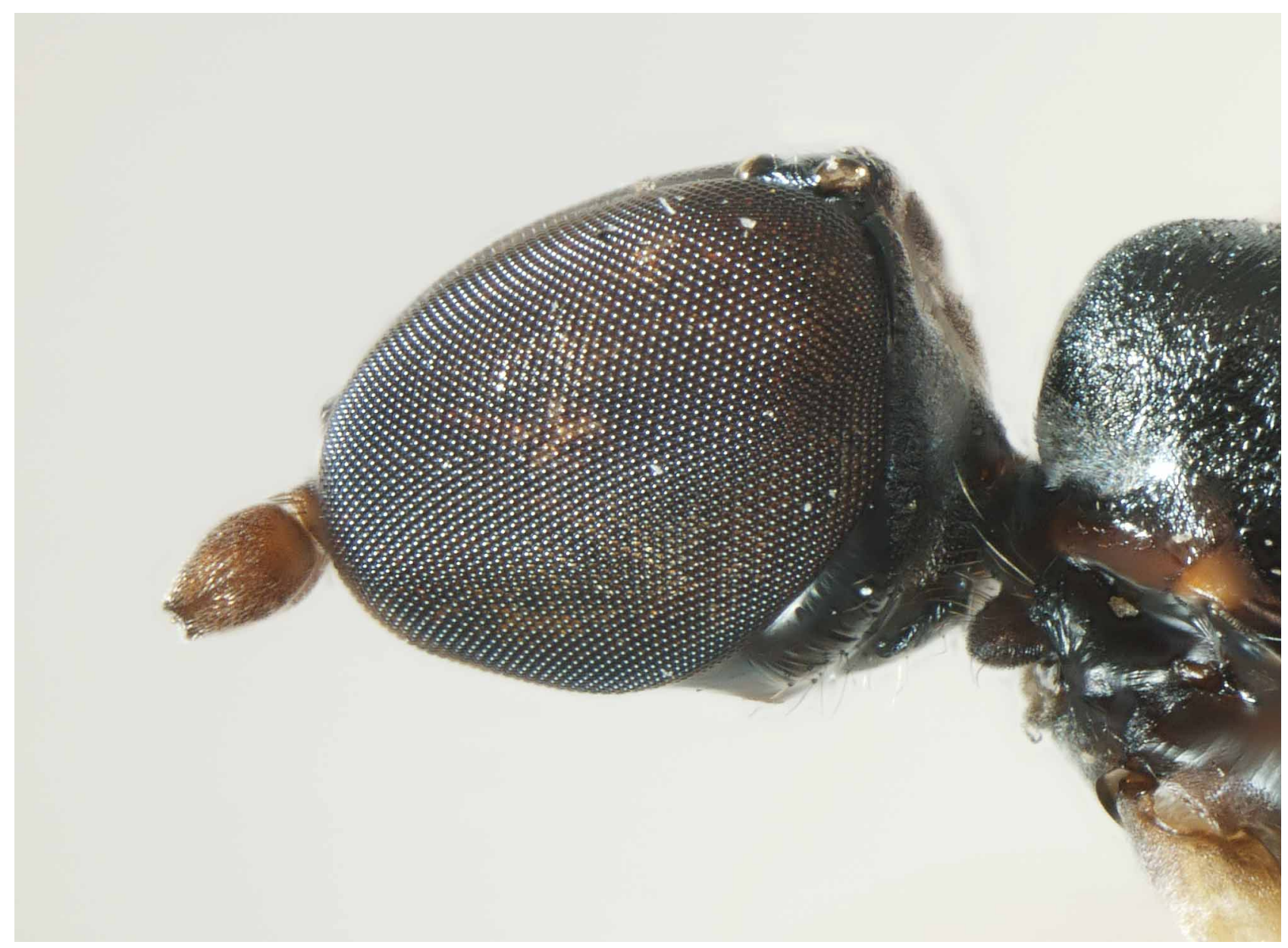

FIGURE 3. Pseudatrichia bezarki sp. nov.: Holotype male, head lateral.

Comments. Pseudatrichia bezarki sp. nov. is closely related to P. punctulata Hardy and P. rufitruncula Kelsey sharing characters such as lateral processes on the apex of the distiphallus, 'tulip'-shaped epandrium, emarginate sternite 8 in female and medially directed cerci in both sexes. This species can be easily diagnosed by the distinctively shaped distiphallus and the shape of female sternite 8 . Unfortunately the number of unassociated males and females described in this genus makes it likely that at least some species may represent the male and female of a single species. The conservative external morphology of adult Pseudatrichia makes it difficult to assess the status of these species based on singular unassociated sexes and will require use of differing characters such as DNA sequence data to test this further. The association of the different sexes in P. bezarki sp. nov. is based on rearing data from a single collecting event, and it is most likely they represent the same species.

Etymology. The specific epithet is named after Larry Bezark, one of the collectors of this species.

To key out $P$. bezarki sp. nov. the following couplets should be included in the dichotomous key by Kelsey (1969), with reference to subsequent modifications by Kelsey $(1971,1974)$ :

\section{Males:}

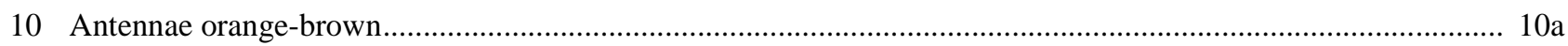

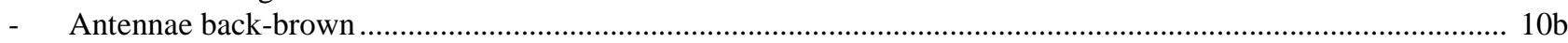

10a Seventh abdominal segment elongate, red-brown; $9^{\text {th }}$ segment black-brown; gonostylar setal brushes extending to apex of distiphallus; distiphallus with paired, spiral-shaped, distal processes relatively long ...P. rufitruncula Kelsey

- Seventh abdominal segment short, glossy black; $9^{\text {th }}$ segment black; gonostylar setal brushes extending to middle of distiphallus; distiphallus with paired, spiral-shaped, distal processes relatively long. P. gracilipennis Kelsey 
- $\quad$ Seventh abdominal segment elongate, glossy black; $9^{\text {th }}$ segment black; gonostylar setal brushes not extending posteriorly beyond end of gonocoxites; distiphallus with paired, distal processes curved and relatively short

P. bezarki sp. nov.

$10 \mathrm{~b}$ Vein $\mathrm{R}_{4}$ arising from middle of cell $\mathrm{r} 5$.

P. unicolor Coquillett

- $\quad$ Vein $\mathrm{R}_{4}$ arising from distal third of cell $\mathrm{r} 5$ P. macalpeni Kelsey

\section{Female:}

15 Vein $\mathrm{R}_{4}$ branching from just beyond the middle of cell $\mathrm{r} 5$

- $\quad$ Vein $\mathrm{R}_{4}$ branching from near the distal fourth of cell $\mathrm{r} 5$ P. cajoni Kelsey

15a Posterior margin of sternite 8 medially emarginate as in Figure $4 \mathrm{C}$; cerci directed medially. P. bezarki sp. nov.

- $\quad$ Posterior margin of sternite 8 not emarginate; cerci parallel along entire length, not directed medially P. atombomba Kelsey

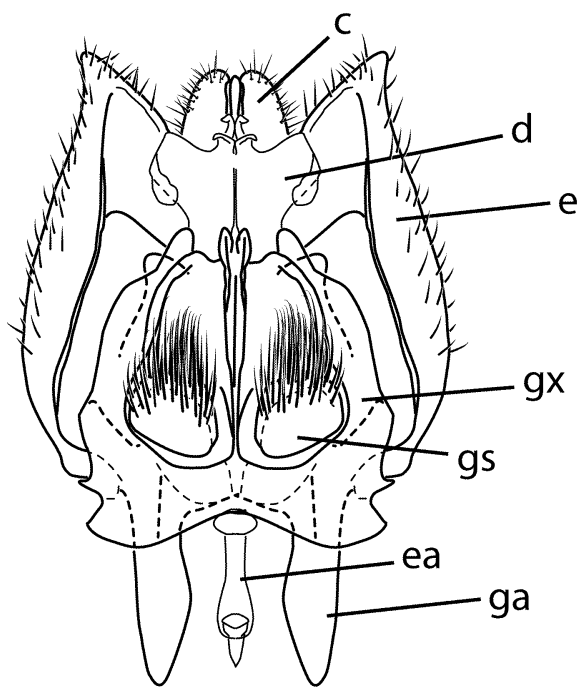

A
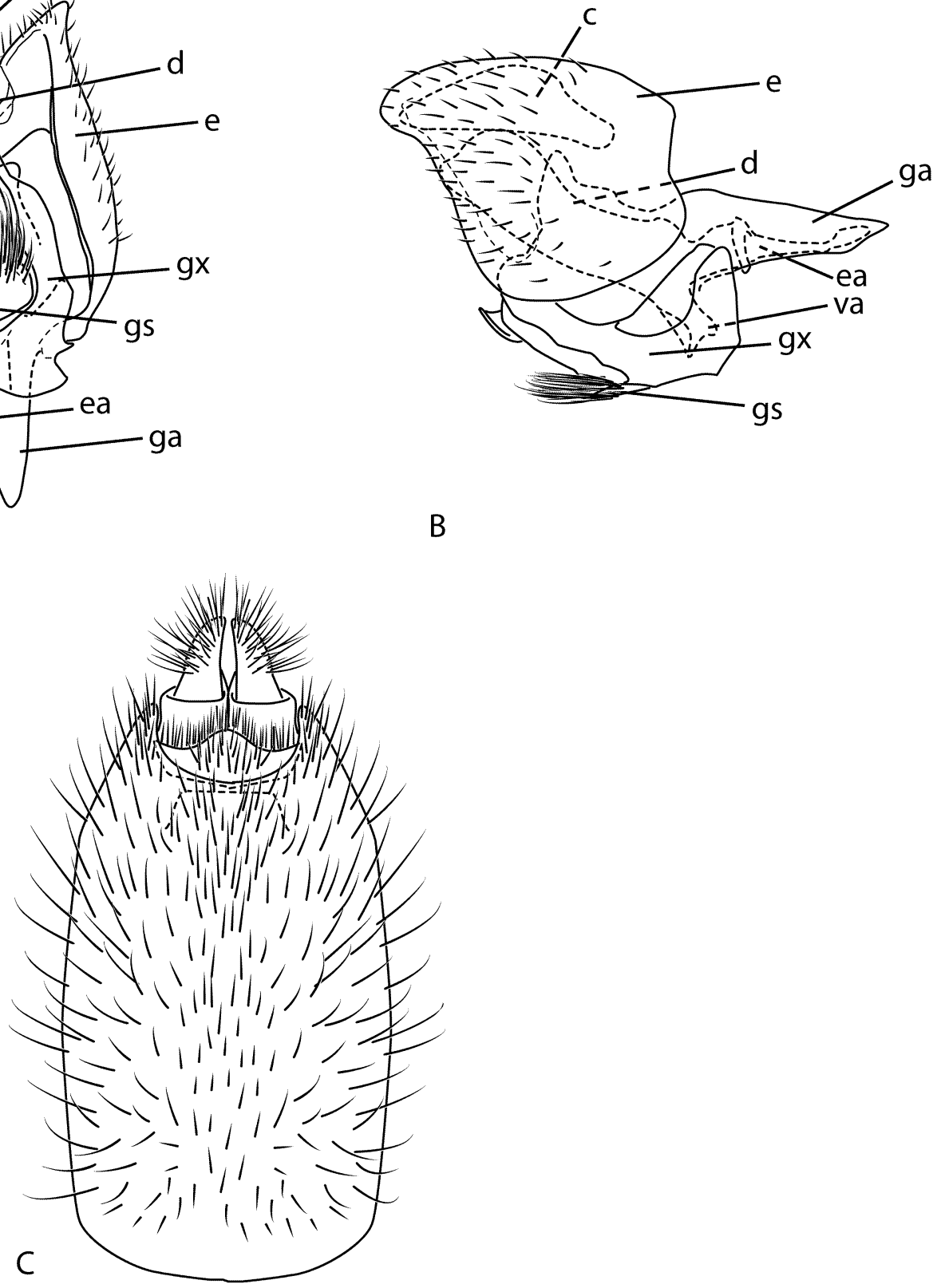

FIGURE 4. Pseudatrichia bezarki sp. nov.: A, male terminalia, (physically) dorsal view; B, same, lateral view; C, female terminalia, ventral view. Abbreviations: $c$, cercus; $d$, distiphallus; $e$, epandrium; $e a$, ejaculatory apodeme; $g a$, gonocoxal apodeme; $g s$, gonostylus; $g x$, gonocoxite; $v a$, ventral apodeme. Scale line: $0.2 \mathrm{~mm}$. 


\section{Acknowledgements}

Special mention should be made of the late Dr Lewis Kelsey, who originally identified this species as new, and even deposited the type series in the CASC, but was unable to publish a description before his death. Thank you to Drs Martin Hauser and Donald Webb for their valuable comments on the draft manuscript. This research was supported by a National Science Foundation (USA) grant (DEB-0614213). Statements and viewpoints expressed herein do not necessarily reflect the opinion of NSF.

\section{References}

Kelsey, L.P. (1969) A revision of the Scenopinidae (Diptera) of the world. Bulletin of the United States National Museum, 277, 1-336.

Kelsey, L. P. (1971) New Scenopinidae (Diptera) from North America. California Academy of Sciences, Occasional Papers, 88, 1-65.

Kelsey, L.P. (1973) The zoogeographic distribution of known Scenopinidae (Diptera). Entomological News, 84, 329-332.

Kelsey, L. P. (1974) Eleven new Scenopinidae (Diptera) from the Americas. Quaestiones Entomologicae, 10, 131-147.

Osten Sacken, C.R. (1877) Western Diptera: Descriptions of new genera and species of Dipterafrom the region west of the Mississippi and especially from California. Bulletin of the United States Geological and Geographical Survey of the Territories, 3, 189-354. 